\title{
Gas chromatography-mass spectrometry chemical profile investigation and biological activities of ethylacetate fraction of Baobab (Adansonia digitata L.) pulp used in the treatment of urinary tract infections
}

\begin{tabular}{|c|c|}
\hline \multicolumn{2}{|c|}{$\begin{array}{l}\text { Authors: } \\
\text { Kehinde O. Fagbemi }{ }^{1} \text { ( } \\
\text { Daniel A. Aina }{ }^{1} \\
\text { Roger M. Coopoosamy } \\
\text { Olufunmiso O. Olajuyigbe }{ }^{2}\end{array}$} \\
\hline \multicolumn{2}{|c|}{$\begin{array}{l}\text { Affiliations: } \\
\text { 'Department of Microbic } \\
\text { School of Science and } \\
\text { Technology, Babcock } \\
\text { University, llisan Remo, } \\
\text { Nigeria }\end{array}$} \\
\hline \multicolumn{2}{|c|}{$\begin{array}{l}\text { 2Department of Nature } \\
\text { Conservation, Faculty of } \\
\text { Natural Sciences, } \\
\text { Mangosuthu University of } \\
\text { Technology, Umlazi, Durban, } \\
\text { South Africa }\end{array}$} \\
\hline \multicolumn{2}{|c|}{$\begin{array}{l}\text { Corresponding author: } \\
\text { Olufunmiso Olajuyigbe, } \\
\text { funmijuyigbe12@yahoo.com }\end{array}$} \\
\hline \multicolumn{2}{|c|}{$\begin{array}{l}\text { Dates: } \\
\text { Received: } 02 \text { Apr. } 2021 \\
\text { Accepted: } 07 \text { June } 2021 \\
\text { Published: } 11 \text { Jan. } 2022\end{array}$} \\
\hline \multicolumn{2}{|c|}{$\begin{array}{l}\text { How to cite this article: } \\
\text { Fagbemi, K.O., Aina, D.A., } \\
\text { Coopoosamy, R.M. \& } \\
\text { Olajuyigbe, O.O., 2022, } \\
\text { 'Gas chromatography-mass } \\
\text { spectrometry chemical } \\
\text { profile investigation and } \\
\text { biological activities of } \\
\text { ethylacetate fraction of } \\
\text { Baobab (Adansonia digitata } \\
\text { L.) pulp used in the treatment } \\
\text { of urinary tract infections', } \\
\text { Journal of Medicinal Plants } \\
\text { for Economic Development } \\
\text { 6(1), a117. https://doi. } \\
\text { org/10.4102/jomped. } \\
\text { v6i1.117 }\end{array}$} \\
\hline \multicolumn{2}{|l|}{ Read or } \\
\hline 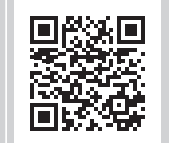 & $\begin{array}{l}\text { Scan this QR } \\
\text { code with your } \\
\text { smart phone or } \\
\text { mobile device } \\
\text { to read online. }\end{array}$ \\
\hline
\end{tabular}

Background: As a result of high percentage of women infected with urinary tract infection (UTI) annually, many rural dwellers use Adansonia digitata fruit pulp as herbal cure. Adansonia digitata L. (Malvaceae) is one of the great trees idolised in Africa because of its therapeutic properties.

Aim: This study aimed at identifying chemical compounds in the ethylacetate fraction of the baobab fruit pulp and indicated their biological activities to justify its use for the folkloric treatment of UTI.

Methods: The crude extract from Baobab fruit pulp was partitioned and ethylacetate extract was used for assay. Gas chromatography-mass spectrometry (GC-MS) analysis was performed to identify the bioactive compounds in the ethylacetate fraction, antioxidant activity was evaluated using 2, 2-diphenyl-1-picrylhydrazyl (DPPH) and ferric reducing antioxidant power (FRAP) assays whilst the total phenolic and flavonoid contents were determined by already adopted protocols. The antibacterial properties were tested against some urinary tract pathogens using macro broth dilution method.

Results: A total of 36 bioactive compounds were identified by GC-MS analysis, most of them have been reported as antibacterial, antioxidant, antidiabetic, antiasthma, antifungal, antiinflammatory and anti-cancer agents. The extract exhibited highest activity against Pseudomonas aeruginosa American Type Culture Collection (ATCC) 19582 (1.22 mg/mL) whilst Escherichia coli ATCC 8739 (> $8.6 \mathrm{mg} / \mathrm{mL})$ displayed high level of resistance amongst the five bacterial isolates used in this study.

Conclusion: These findings indicated that the extract contained bioactive compounds of therapeutic importance with significant antioxidant and antibacterial potentials and justify the folkloric use of this fruit in the treatment of UTIs by many African dwellers.

Keywords: Adansonia digitata; antioxidant; antibacterial; GC-MS analysis; phytochemicals.

\section{Introduction}

Adansonia digitata L. (Malvaceae) is one of the eight species of Adansonia genus that is indigenous to sub-Sahara African. The leaves, seeds and fruit pulp are edible and are consumed majorly by rural dwellers because of the cultural and religious beliefs of the consumers. Almost every part of the tree is valuable. Whilst some even consider the tree as sacred (Muthai et al. 2017) baobab leaves, bark and fruit are used for nutraceutical purposes in many African countries. As a result of the antihistamine and anti-hypertension potentials of the leaves, dry powdered leaves are used as an anti-asthmatic agent (Abiona, Adedapo \& Suleiman 2015). Datsugwai and Yusuf (2017) indicated that the extract from the stem was capable of inhibiting some urinary tract pathogens such as Escherichia coli, Klebsiella pneumoniae, Proteus mirabilis and Staphylococcus species. Abdallah and Ali (2018) reported that the leaf extracts were significantly potent against some enteric pathogens. Lisao, Geldenhuys and Chirwa (2017) reported that the leaves were used as a healing therapy for cough in northern Namibia. Kehlenbeck, Padulosi and Alercia (2015) reported that the presence of high concentration of essential amino acid in the seed makes it a good source of protein and hence it is roasted and consumed as snacks in some African countries. Its application in folk

Copyright: @ 2022. The Authors. Licensee: AOSIS. This work is licensed under the Creative Commons Attribution License. 
medicine cannot be underestimated as Sodimu et al. (2020) further indicated the effectiveness of Baobab in the treatment of infections in traditional Africa communities. The oil extracted from the seed has been reported to be widely used in chemotherapy and in the cosmetic industries because of the presence of palmitic, linoleic and oleic acids (Komane et al. 2017).

Baobab fruits are large gourd-like structures with wooden velvety skin (Sundarambal, Muthusamy \& Radha 2015). The gourd contains many seeds surrounded with white powdery pulp having a high content of vitamin C almost 10 times higher than that from citrus orange (Kehlenbeck et al. 2015). The powdery pulp is used in local beverage preparation and local candies (De Caluwé, Halamová \& Van Damme 2010). Some researchers considered it as a food supplement and recommended for daily consumption to give energy, carbohydrates and proteins especially to children and pregnant women. In African traditional medicine, the pulp is utilised locally as an antipyretic, anti-dysenteric, diaphoretic, immunostimulant, anti-inflammatory, analgesic and probiotic agent (Braca et al. 2018). The pulp exhibits numerous medicinal properties such as antioxidant activity (Tembo, Holmes \& Marshall 2017), hepatoprotective effect (Hanafy et al. 2016), cardioprotective effect (Ghoneim et al. 2016) and antidiabetic and anti-cholesterol potential (Ebaid et al. 2019). Although the pulp is relatively low in protein content (Chadare et al. 2008), it could also serve as a good source of amino acids and a low glycaemic index food because of its low sugar content as well. Despite numerous reports on the nutritional and chemical composition of Baobab fruit pulp, there is a dearth of information on its different chemical compounds elucidated by gas chromatography-mass spectrometry (GC-MS) analysis and the biological activities of each compound contributing to rationale for its recognition as a functional food and as curative agent for urinary tract infection (UTIs) in folk medicine in some local villages in Nigeria. This study therefore investigated the bioactive compounds in the ethylacetate fraction of baobab pulp and its biological activities.

\section{Materials and methods Collection of plant samples}

The entire gourd of healthy and disease-free samples of Adansonia digitata L. fruit was collected from the wild in Michika local government area of Adamawa state, Nigeria in April 2019. It was identified ethnobotanically and confirmed by a medicinal plant specialist in the University of Lagos, Lagos and the voucher number is LUH: 8772. Michika, a Local government in Adamawa state, is located in the north eastern part of Nigeria. Its geographical coordinates are $10^{\circ}$ $37^{\prime} 5^{\prime \prime}$ north, $13^{\circ} 23^{\prime} 22^{\prime \prime}$ east.

\section{Chemical reagents}

All chemical reagents used for this investigation were of analytical grade. Reagent such as 2, 2-diphenyl-1picrylhydrazyl, ferrous chloride, ferrozine, sodium sulfate, gallicacid, trolox(6-hydroxy-2,5,7,8-tetramethylchroman-2carboxylic acid), TPTZ (2, 4, 6-tripyridyl-s-triazine), iron (III) chloride hexahydrate $\left(\mathrm{FeCl}_{3} \cdot 6 \mathrm{H}_{2} \mathrm{O}\right)$ and Folin-Ciocalteau were purchased from Sigma-Aldrich (Germany). Sodium acetate trihydrate $\left(\mathrm{C}_{2} \mathrm{H}_{3} \mathrm{NaO}_{2}\right)$, sodium hydroxide $(\mathrm{NaOH})$, methanol, acetone, acetic acid glacial, chloridric acid and sodium carbonate were purchased from Synth (Brazil) and gallic acid was purchased from Vetec (Brazil).

\section{Extraction of baobab pulp and preparation of extracts}

This was carried out by method described by George, Saewan and Ali (2019) with slight modifications. Gourds were broken and the white powdery pulp was collected before being pounded with cleaned mortar and pestle to separate the seeds from the powdery substance. A total of $80 \mathrm{~g}$ of pulverised baobab fruit pulp was dispersed into $640 \mathrm{~mL}$ of $70 \%$ methanol and was continuously agitated with rotary shaker (Stuart Scientific Orbital Shaker, United Kingdom) for $72 \mathrm{~h}$ for proper digestion before being filtered through a Whatmann No. 1 filter paper. The filtrate was concentrated with a rotary vacuum evaporator (Laborota 4000-efficient, Germany) at $40{ }^{\circ} \mathrm{C}$ under pressure. The semisolid crude extract was dried in an oven and stored at $4{ }^{\circ} \mathrm{C}$ for further use.

\section{Solvent-solvent partitioning}

Solvent-solvent partitioning was carried out on the crude extract by adopting the method designed by Emran et al. (2015) and with slight modification. Briefly, a stock solution was prepared by dissolving $2 \mathrm{~g}$ of the crude extract in $10 \%$ methanol and was partitioned by three solvents based on the order of their increasing polarities in a separating funnel. The solvents used include n-hexane, ethylacetate and water.

\section{n-Hexane partition}

The nonpolar compounds were separated by dissolving $1 \mathrm{~g}$ of the hydro methanolic extract of Adansonia digitata fruit pulp in $20 \mathrm{~mL}$ of distilled water and $20 \mathrm{~mL}$ of $100 \% \mathrm{n}$-hexane was added to the extract in a separating funnel. The n-hexane layer was collected and concentrated under vacuum in a rotary evaporator. Ethylacetate partitioning was carried out to the aqueous layer obtained from the n-hexane partitioning procedure. The same process carried out for the n-hexane was repeated by adding $10 \mathrm{~mL}$ of $100 \%$ ethylacetate, the layer was collected and stored. The aqueous layer was also collected and concentrated like the previous one and stored for further use.

\section{Gas chromatography-mass spectrometry analysis}

The GC-MS analysis of the ethylacetate fraction of the fruit extract was carried out in a (QP 2010 Plus SHIMADZU) instrument at $70 \mathrm{eV}$. One microlitre $(1 \mathrm{uL})$ of the extract was injected into the GC-MS using a micro syringe and the scanning was performed for $24 \mathrm{~min}$. 


\section{Determination of minimum inhibitory concentrations}

Bacteria isolates used for this work include E. coli ATCC 8739, K. pneumoniae ATCC 10031, Pseudomonas aeruginosa ATCC 19582, Acinetobacter calcaoceuticus UP and Staphylococcus aureus ATCC 6558. These test isolates were obtained from Department of Microbiology, Babcock University, Ilisan Remo, Ogun State, Nigeria. All isolates were inoculated in nutrient broth and incubated at $37^{\circ} \mathrm{C}$ for $24 \mathrm{~h}$ before being used for antimicrobial activities. The extract was redissolved in $1 \%$ dimethylsulfoxide (DMSO). The reconstituted extract was assessed for sterility by dispensing $2 \mathrm{~mL}$ of the extract into $10 \mathrm{~mL}$ of sterile nutrient broth before incubating at $37^{\circ} \mathrm{C}$ for $24 \mathrm{~h}$. After the incubation period, a clear extract without turbidity showed that the extract was sterile. The method of Olajuyigbe and Afolayan (2012) was adopted. Briefly, $1 \mathrm{~mL}$ of the stock solution of the crude extract and the antibiotics (positive control) at concentrations ranging between $1 \mathrm{mg} / \mathrm{mL}$ and $70 \mathrm{mg} / \mathrm{mL}$ for the extract and $0.00488 \mu \mathrm{g} / \mathrm{mL}$ and $5 \mu \mathrm{g} / \mathrm{mL}$ for ciprofloxacin used as standard drug were prepared by serial dilution in double strength Mueller Hinton broth. In addition, the turbidity of overnight broth cultures of the organisms was adjusted to 0.5 McFarland standards and $100 \mu \mathrm{L}$ of the different organisms were dispensed into all the test tubes containing serially diluted extract and ciprofloxacin antibiotics except the control after the standardisation. The test tubes were incubated for $18 \mathrm{~h}-$ $24 \mathrm{~h}$ at $37^{\circ} \mathrm{C}$. The test tubes were observed for any visible growth or turbidity in the culture. The lowest concentrations that showed no visible growth or turbidity were taken as the minimum inhibitory concentrations (MICs).

\section{Determination of antioxidant activity}

Two different antioxidant assays, DPPH and ferric reducing antioxidant power (FRAP) were carried out to determine the antioxidant activity of the ethylacetate fraction of the hydro methanol extract of the fruit pulp.

\section{2, 2-diphenyl-1-picrylhydrazyl radical scavenging method}

The method of Goswami and Chatterjee (2014) was adopted for DPPH scavenging. Briefly, five different concentrations $(1 \mathrm{~mL})$ of the ethylacetate extract were thoroughly mixed with $0.2 \mathrm{mM}$ of DPPH in an ethanol solution. The samples were incubated in a dark room for half an hour after vigorous shaking and the absorbance was measured at $517 \mathrm{~nm}$. Gallic acid was used as a standard and ethanol as a control. The scavenging potential of the extract was calculated as the percentage inhibition of absorbance by applying the following formulae: Scavenging activity $(\%)=($ Ac-As $) / A c \times$ 100. Where $A c$ is the absorbance of the control and As is absorbance of the sample.

\section{Determination of total phenolics}

To evaluate the total phenolic content (TPC) of the sample, the method of Folin-Ciocalteu was adopted (Santos-Sánchez et al. 2019). Ethylacetate extract of $1 \mathrm{~mL}$ was dispensed in a test tube and was thoroughly mixed with $1 \mathrm{~mL}$ of Folin-
Ciocalteu reagent (initially diluted 6-fold with water). This was followed by adding $2 \mathrm{~mL}$ of $20 \%(\mathrm{w} / \mathrm{v})$ of sodium carbonate. The mixture was kept in a dark room for $30 \mathrm{~min}$ and absorbance was measured by a ultraviolet visible spectrophotometer (UV-Vis) (Jascov-530) at a wavelength of $765 \mathrm{~nm}$. Gallic acid was used as a standard. The assay was carried out in triplicate and results were expressed as milligrams gallic acid/gram of the dried extract.

\section{Ferric reducing antioxidant power}

The FRAP assay was carried out using the method described by Benzie and Devaki (2018). Briefly, the FRAP reagent was prepared by mixing $100 \mathrm{~mL}$ of acetate buffer at $30 \mathrm{mM}, 10 \mathrm{~mL}$ of a $10 \mathrm{mM}$ 2,4,6-tripyridyl-s-triazine (TPTZ) in $40 \mathrm{mM}$ hydrochloric acid $(\mathrm{HCl})$ and $10 \mathrm{~mL}$ of $\mathrm{FeCl}_{3} \cdot 6 \mathrm{H}_{2} \mathrm{O}$ at $20 \mathrm{mM}$. Then, $3 \mathrm{~mL}$ of freshly prepared FRAP solution was vigorously mixed with $100 \mu \mathrm{L}$ of the ethylacetate extract. There was formation of blue colour complex when ferric tripyridyl triazine $\left(\mathrm{Fe}^{3+}\right.$ TPTZ) complex was turned to ferrous $\left(\mathrm{Fe}^{2+}\right)$ form after incubating for $30 \mathrm{~min}$ at $37^{\circ} \mathrm{C}$ and the absorbance was measured at $593 \mathrm{~nm}$. A freshly prepared working solution of $\mathrm{FeSO}_{4}$ was used for calibration. All determinates were carried out in triplicates and expressed as gallic acid equivalents (GAE) in mg per gram dry weight.

\section{Determination of the total flavonoid content}

Flavonoids, with potentials depending on the number and position of free hydroxyl $(\mathrm{OH})$ groups, are phytochemicals with antioxidant activity. The total flavonoid content of the ethylacetate extract was measured by the aluminum chloride colorimetric assay for quantitative determination. Briefly, $2.8 \mathrm{~mL}$ of double distilled water was mixed with $1 \mathrm{~mL}$ of the crude extract and with $0.1 \mathrm{~mL}$ of $1 \mathrm{mg} / \mathrm{mL}$ potassium acetate solution. Then, $0.1 \mathrm{~mL}$ of $10 \%$ aluminum chloride was added to this solution, it was allowed to stand for $30 \mathrm{~min}$ and the absorbance was measured at $415 \mathrm{~nm}$ by using a ultraviolet visible spectrophotometer (Shimadzu). The total flavonoid content was expressed as GAE in milligram/gram dry weight. All determinants were carried out in triplicates.

\section{Statistical analysis}

Statistical comparisons were performed with one-way analysis of variance and $p$-values $<0.05$ were regarded as significant. Correlation coefficients $(\mathrm{R})$ to determine the correlation among DPPH, FRAP assay, TPC and total flavonoid contents (TFC) were evaluated by MS Excel software (CORREL statistical function).

\section{Results}

The ethyl acetate fraction was analysed with GC-MS to have insight into the compounds present in the fraction. The GC-MS chromatogram of these chemical compounds is presented in Figure 1 and their composition percent, name of compounds, chemical structure and their biological activities are represented in Table 1. From the GC-MS analysis, 37 identified compounds 


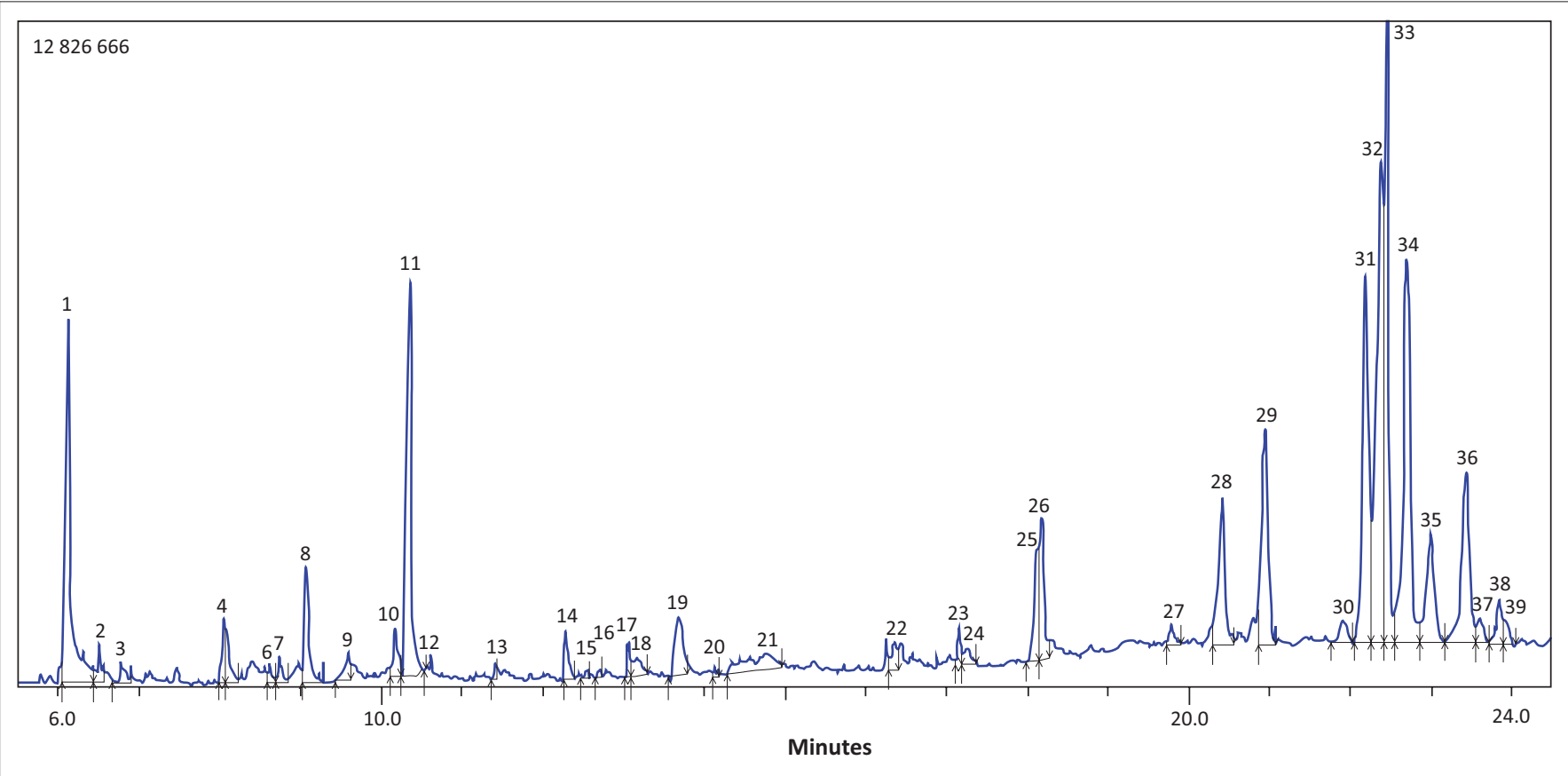

FIGURE 1: Gas chromatography-mass spectrometry chromatogram of the bioactive compounds in the ethyl acetate extract of Adansonia digitata.

were expressed as percentages of the composition relative to the total composition. Compounds with greater than or equal to $1.0 \%$ composition were identified as the prominent chemical compounds. The prominent chemical compounds are longifolenaldehyde (1.04\%), 4H-pyran-4-one, 2,3-dihydro-3,5dihydrox $(1.82 \%)$, beta-D-glucopyranose $(1.93 \%)$, alpha-Dglucopyranoside $(1.97 \%)$, campesterol $(3.74 \%)$, vitamin E $(4.58 \%)$, stigmasterol (5.56\%), 2,5-furandione, dihydro-3methylene- (7.86\%), 5-hydroxymethylfurfural (8.59\%), 5.beta.,7. beta.H,10.alpha.-eudesm-11-en-1 (13.03\%), gamma.-sitosterol (9.47\%), beta.-sitosterol (13.54\%) and 4,4,6a,6b,8a,11,11,14boctamethyl-,4,4a,5,6,6a,7,8,8a,9,10,11,12,12a,14,14a,14b,octadecahydro-2H-picen-3-one (16.22\%). The pharmacological activities of 4,4,6a,6b,8a,11,11,14b-octamethyl-,4,4a,5,6,6a,7,8,8a, 9,10,11,12,12a,14,14a,14b,-octadecahydro-2H-picen-3-one with the percentage composition and those of other chemical compounds have been reported as being of therapeutic importance whilst those of 6-octen-2-one, (Z)- (0.1\%), 3-hexanol, 3-ethyl- (0.31\%) and adenosine, N6-phenylacetic acid $(0.71 \%)$ with lower composition percentages, having no reported pharmacological activities are as shown in Table 1.

The potential of the ethylacetate extract of $A$. digitata extract to inhibit the growth of the test organisms was as shown in Table 2. The result showed the potential to inhibit the growth of the bacterial isolates at varied concentrations. Pseudomonas aeruginosa ATTC 19582 was the most susceptible at MIC of $1.22 \mathrm{mg} / \mathrm{mL}$. Whilst K. pneumoniae ATCC 10031, Staphylococcus aureus ATTC 6558 and Acinetobacter calcaoceuticus UP had the same MIC of 2.43 $\mathrm{mg} / \mathrm{mL}$, Escherichia coli ATCC 8739 showed some level of resistance with MIC greater than $8.6 \mathrm{mg} / \mathrm{mL}$ and the MIC of ciprofloxacin was used as control against the bacterial isolates ranged between $0.0195 \mu \mathrm{g} / \mathrm{mL}$ and $1.25 \mu \mathrm{g} / \mathrm{mL}$.
The ethylacetate fraction exhibited the highest DPPH scavenging activities at $71.31 \mu \mathrm{g} / \mathrm{mL}$ compared with the standard (gallic acid) whose value was at $84.62 \mu \mathrm{g} / \mathrm{mL}$. Ferric reducing antioxidant power was carried out to determine the antioxidant properties of ethyl acetate fraction based on its ability to reduce ferric (III) to ferrous (II). The ethylacetate fraction showed maximum activity with FRAP value at $233.59 \mu \mathrm{g} / \mathrm{mL}$. The total phenolic and flavonoid content of the ethylacetate fraction was assessed and compared with that of the standard (gallic acid). The value obtained showed that the ethylacetate fraction has the higher phenolic and flavonoid content of 438.68 and 154.01 ( $\mu \mathrm{gGAE} / \mathrm{mL})$, respectively.

To show that a relationship existed between the TPC, TFC, radical scavenging activities (DPPH) and FRAP of the fractions, a statistical analysis was performed to find the correlation coefficient (R) of the fraction. From the analysis of the relationship, the radical scavenging activities and the TPC was $R=0.9113$. The $R$ value between the FRAP and phenolic content was $R=0.952$. Such high $R$ value between the DPPH radical scavenging activities and TPC could be used to predict the antioxidant potential of a sample. It was observed that the significant correlations existing between the total antioxidant capacities and TPCs and TFCs of the fractions show that the antioxidant potentials of the extracts are embedded in the phenolic and flavonoids contents.

\section{Discussion}

In recent years, there has been increase in demand for medicinal plants in the treatment of many infections including UTI. Although several antibiotics have been prescribed to patients, but because of development of 
TABLE 1: Chemical compounds in ethylacetate extract of Adansonia digitata identified by gas chromatography-mass spectrometry.

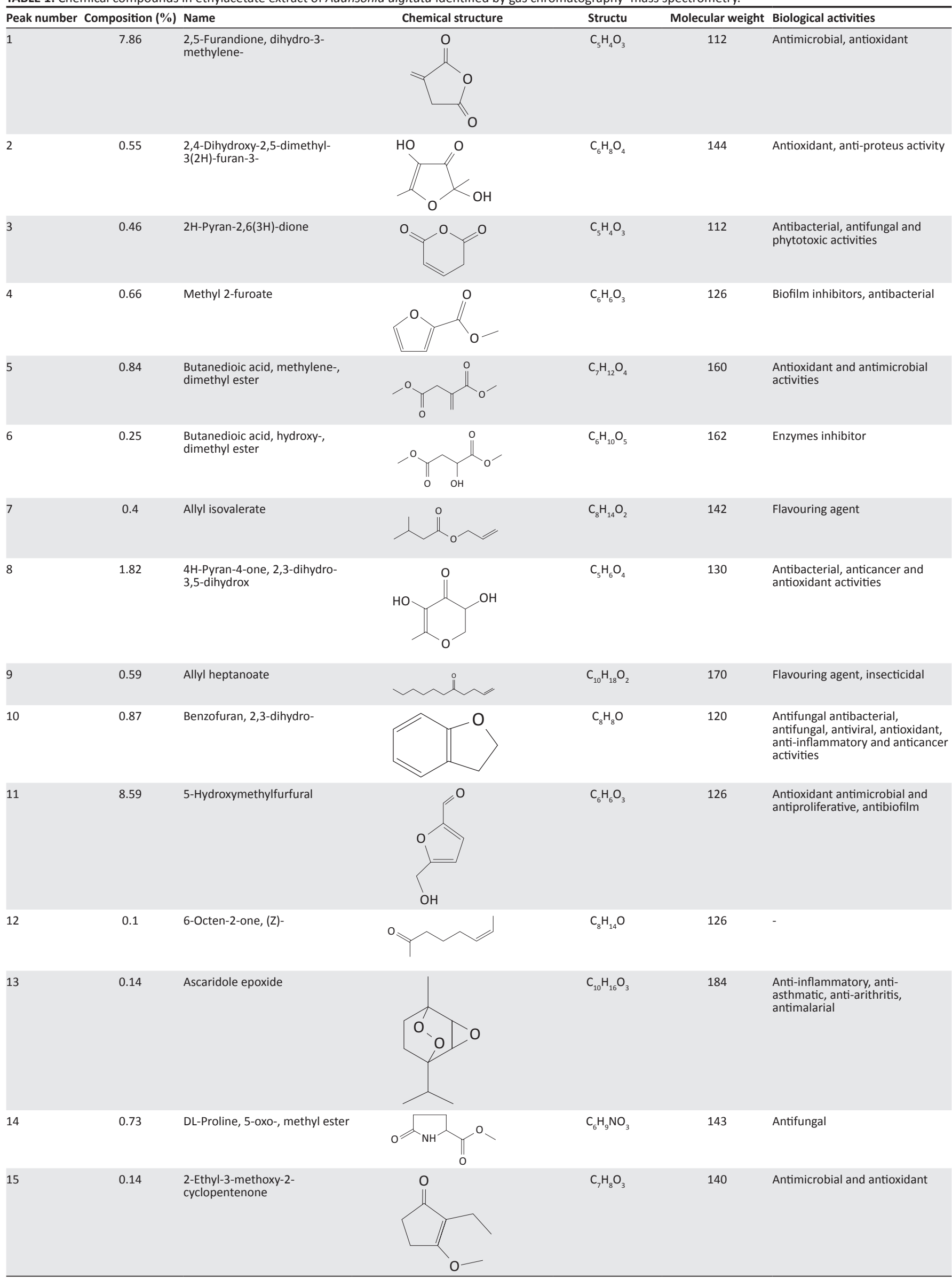


TABLE 1 (Continues...): Chemical compounds in ethylacetate extract of Adansonia digitata identified by gas chromatography-mass spectrometry. Peak number Composition (\%) Name

\section{Chemical structure}

$16 \quad 0.06 \quad$ 1-Di(tert-butyl)silyloxydodecane

17

$0.31 \quad 3-H e x a n o l, 3-e t h y l-$

0.71 Adenosine, N6-phenylacetic acid

18

acid

$x_{\mathrm{si}^{\mathrm{s}}-\mathrm{N}}$

Structu

$\mathrm{C}_{20} \mathrm{H}_{44} \mathrm{OSi}$

$$
\mathrm{C}_{8} \mathrm{H}_{18} \mathrm{O}
$$

$\mathrm{C}_{18} \mathrm{H}_{19} \mathrm{~N}_{5} \mathrm{O}_{6}$

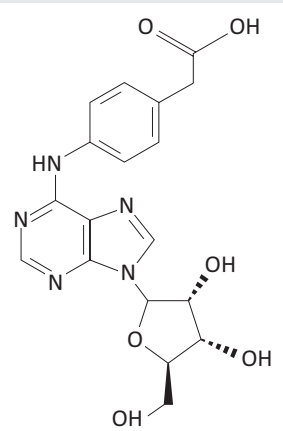

Molecular weight Biological activities

328

130

401

$\mathrm{C}_{6} \mathrm{H}_{10} \mathrm{O}_{5} \quad 162$

252 Antimicrobial, antioxidant

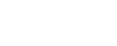

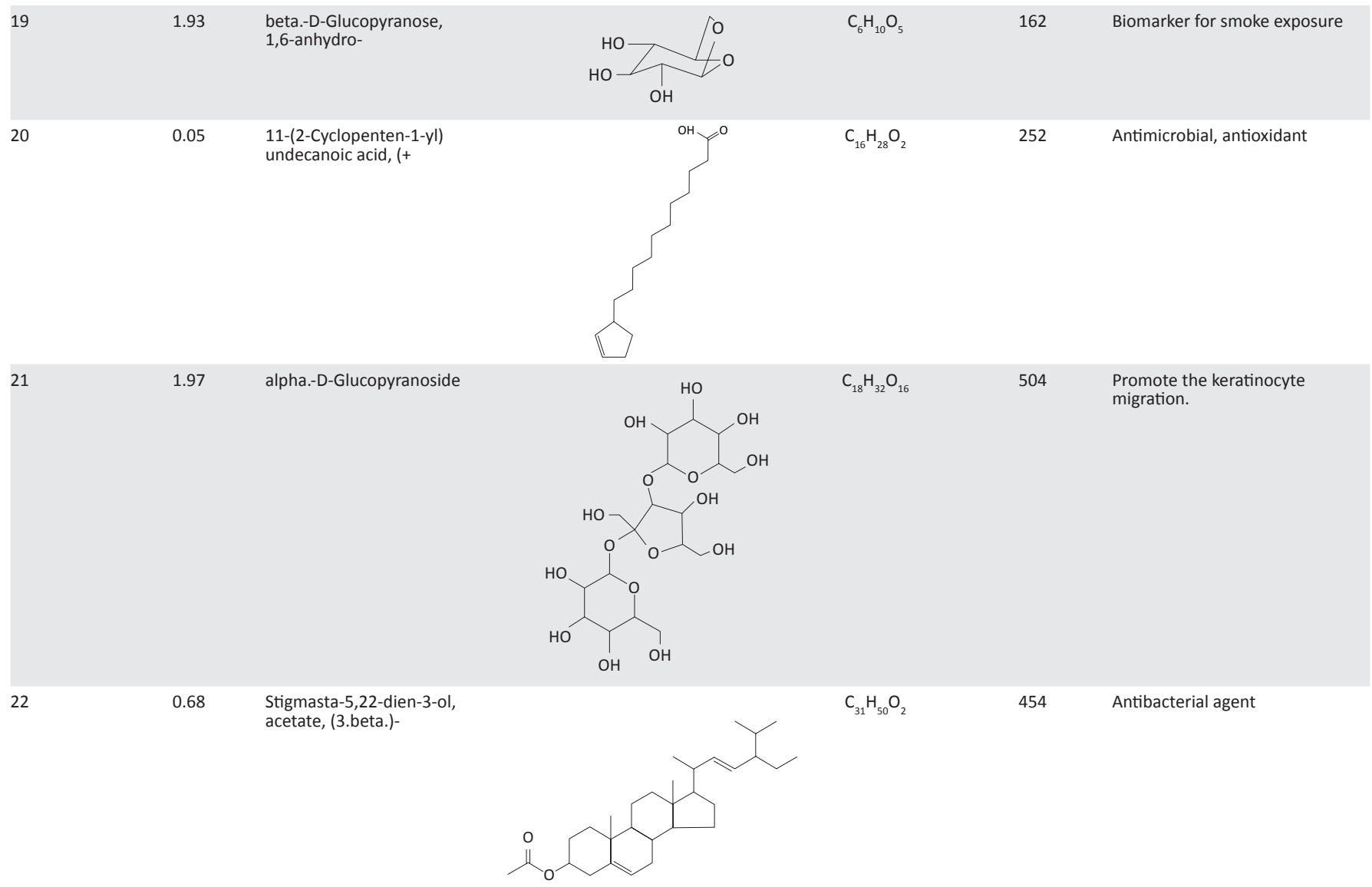

23 0.39

Eicosanoic acid

$\mathrm{C}_{20} \mathrm{H}_{40} \mathrm{O}_{2}$

$\mathrm{C}_{20} \mathrm{H}_{32} \mathrm{O}$

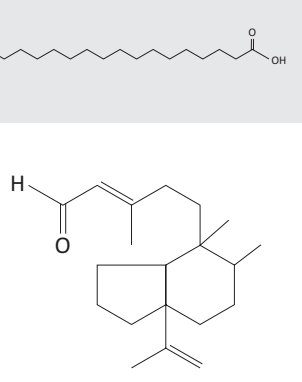

312 Antimicrobial and antifungal

288

Antimicrobial and antioxidant

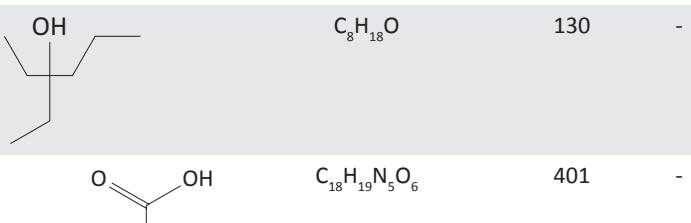


TABLE 1 (Continues...): Chemical compounds in ethylacetate extract of Adansonia digitata identified by gas chromatography-mass spectrometry. Peak number Composition (\%) Name

$\begin{array}{llcl}\text { Chemical structure } & \text { Structu } & \text { Molecular weight } & \text { Biological activities } \\ \mathrm{C}_{29} \mathrm{H}_{50} \mathrm{O}_{2} & 430 & \begin{array}{l}\text { Powerful antioxidant and } \\ \text { hepatoprotective }\end{array} \\ & 222 & \text { Antitumour and antifungal }\end{array}$

26 $0.42 \quad 2 \mathrm{H}-3,9 a-M e t h a n o-1-$ benzoxepin<smiles>CC1C2CCCC1(C)CC(C)(C)O2</smiles>

$\mathrm{C}_{15} \mathrm{H}_{26} \mathrm{O}$

222

Antitumour and antifungal

27

3.74 Campesterol

$\mathrm{HO}$

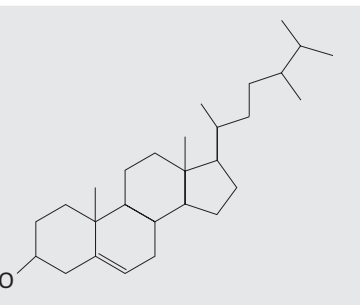

28

$5.56 \quad$ Stigmasterol

$\mathrm{C}_{28} \mathrm{H}_{48} \mathrm{O} \quad 400 \quad$ Anti-inflammatory

$\mathrm{C}_{29} \mathrm{H}_{48} \mathrm{O}$

412

Antitumor, anti-nociceptive and antidiabetic

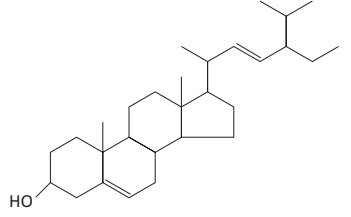

29

$0.69 \quad$ Menthol, 1'-(butyn-3-one-1-

yl)-, (1R,2S,5R

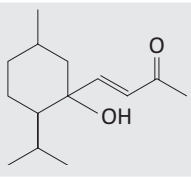

$\mathrm{C}_{14} \mathrm{H}_{22} \mathrm{O}_{2}$

222

Antibacterial and Antioxidant

$30 \quad 13.03 \quad \begin{aligned} & 5 \text { beta, } 7 . \text { beta.H,10.alpha.- } \\ & \text { Eudesm-11-en-1. }\end{aligned}$

$\mathrm{OH}$<smiles>C=C(C)C1CCC2(C)C(C)CCC(C)C2C1</smiles>

31

13.54 beta-Sitosterol<smiles>C=CC(CCC(C)C1CCC2C3CC=C4CC(O)CCC4(C)C3CCC12C)C(C)C</smiles>

$\mathrm{C}_{29} \mathrm{H}_{50} \mathrm{O}$

414

Anti-inflammatory antimicrobial, anti-helminthic, anti-mutagenic anticancer, hepatoprotective and diuretic

HO

32

9.47 gamma-Sitosterol

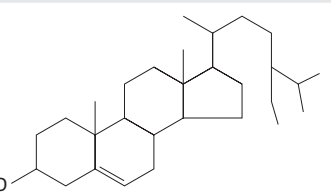

$\mathrm{C}_{29} \mathrm{H}_{50} \mathrm{O}$

414

Antimicrobial and anticancer

HO

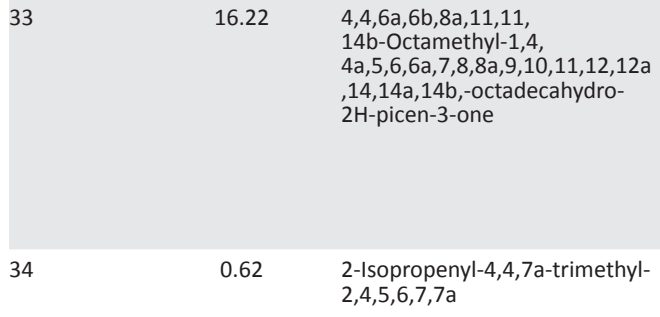

(c)

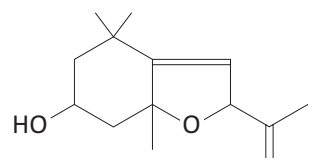

35

1.04

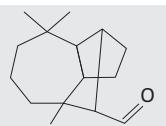

$\mathrm{C}_{30} \mathrm{H}_{48} \mathrm{O}$

424

Anti-cancer, antioxidant,

antifungal and

hypocholesterolemic

$\mathrm{C}_{14} \mathrm{H}_{22} \mathrm{O}_{2}$

$222 \quad$ Antifouling

$\mathrm{C}_{15} \mathrm{H}_{24} \mathrm{O}$

220

Antifungal activities 
TABLE 1 (Continues...): Chemical compounds in ethylacetate extract of Adansonia digitata identified by gas chromatography-mass spectrometry.

\begin{tabular}{|c|c|c|c|c|c|c|}
\hline Peak number & Composition (\%) & Name & Chemical structure & Structu & Molecular weight & Biological activities \\
\hline 36 & 0.54 & $\begin{array}{l}\text { Ergosta-7,22-dien-3-ol, } \\
\text { (3.beta.,22E)- }\end{array}$ & & $\mathrm{C}_{28} \mathrm{H}_{46} \mathrm{O}$ & 398 & Antitumor and antioxidant \\
\hline
\end{tabular}

TABLE 2: Minimum inhibitory concentration of ethylacetate fraction of Adansonia digitata extract on the bacterial isolates.

\begin{tabular}{lcc}
\hline Test organisms & $\begin{array}{c}\text { Ethylacetate extract MIC } \\
(\mathrm{mg} / \mathrm{mL})\end{array}$ & $\begin{array}{c}\text { Ciprofloxacin MIC } \\
(\mu \mathrm{g} / \mathrm{mL})\end{array}$ \\
\hline $\begin{array}{l}\text { Klebsiella pneumoniae ATCC } \\
10031\end{array}$ & 2.43 & 0.0195 \\
$\begin{array}{l}\text { Pseudomonas aeruginosa ATCC } \\
19582\end{array}$ & 1.22 & 0.0195 \\
Staphylococcus aureus ATCC 6538 & 2.43 & 0.0391 \\
Acinetobacter calcaoceuticus UP & 2.43 & 1.2500 \\
Escherichia coli ATCC 8739 & $>8.6$ & 0.0195 \\
\hline
\end{tabular}

MIC, minimum inhibitory concentration; ATCC, American Type Culture Collection.

antibiotics resistance, which is a major challenge being faced in the healthcare sectors globally, it is inevitable to seek and optimise a 'non-antibiotic' alternative for curative purposes (Daswani 2019). This has necessitated the application of bioactive compounds with therapeutic potentials in the treatment of urinary tract pathogens. Several studies showed that plants' bioactive compounds could play significant role in the discovery of current and potent drugs being used (Adeoye-Isijola et al. 2021; Olajuyigbe et al. 2018). They have potent antioxidant potentials attributed to the quantity of phenolic content they possessed and act as antioxidant agents.

In this study, the high radical scavenging activities, FRAP and the high phenolic and flavonoid contents in the ethylacetate extract of Baobab fruit pulp could be attributed to the polarity of the solvent enabling the solvent to extract semi-polar and non-polar constituents. This is in agreement with Arowora et al. (2019) who earlier observed a good antioxidant potential in $70 \%$ ethylacetate fraction of extract from Baobab fruit pulp. The high flavonoid content could have contributed to the high exploitation of the fruit pulp in the treatment of many diseases in folk medicines. This is also in agreement with Rathee et al. (2009) who reported that flavonoids are the most common secondary metabolites in fruits and have the ability to prevent bacteria adherence and inhibit enzymes activities. Furthermore, whilst a significant correlation exists between the antioxidant and TPC in the ethylacetate fraction, the flavonoid exhibited excellent relationship with the DPPH and FRAP activities. Thus, the antioxidant potential of this fraction was because of the presence of phenolic compounds. This report corroborates the findings of Khorasani Esmaeili et al. (2015) indicating that a strong correlation existed between scavenging potential and phenolic content of extracts from different plant origin.
Furthermore, the antibacterial activities of the ethylacetate fraction correlated with its high antioxidant activities. This was also in agreement with Olajuyigbe, Olajuyigbe and Coopoosamy (2020) indicating that the antibacterial activities of medicinal plants could result from the ability of the plant to generate reactive oxygen species as plant extracts do not only function as antioxidant agents.

In addition, pharmacological activities of the compounds identified from the GC-MS showed that the pulp has potential novel compounds that could be isolated for therapeutic purposes. Irrespective of the percentages of the identified chemical compounds, scientific reports showed that each of the compounds possesses significant therapeutic potentials. The most prominent compound included 4,4,6a,6b,8a,11,11,14b-octamethyl-1,4,4a,5,6a,7,8,8a,9,10,11,1 2,12a,14,14a,14b,-octadecahydro-2H-picen-3-one (16.22\%), beta-sitosterol with a content of about (13.54\%), 4,4,6a,6b,8a,11,11,14b-octamethyl-1,4,4a,5 (10.74\%), gammasitosterol $(9.47 \%)$ and 5.beta. 7. beta. H,10.alpha.-eudesm11-en-1 (9.46\%), 5-hydroxymethylfurfural (8.59\%), 2,5-furandione, dihydro-3-methylene- (7.86\%) and Stigmasterol (5.56\%) with several biological activities reported. Awonyemi, Abegunde and Olabiran (2020) reported that the compound with highest composition percentage has antioxidant, antifungal and antiinflammatory potentials whilst Shamma et al. (2018) also documented its anti-neoplastic potential. The betasitosterol, a type of plant sterol, promotes the cytotoxic activities of killer cells by activating T-helper cells (Bin Sayeed et al. 2016). In this study, the tested organisms could have been inhibited by this extract because of the presence of beta-sitosterol and other compounds, which have been reported to have antimicrobial potentials although their real mode of action on microorganisms is not yet clearly understood. Whilst Elfadil et al. (2015) that showed that beta-amyrone possessed antimicrobial potential, this study corroborates the findings of Saeidnia et al. (2014) indicating that E. coli, K. pneumoniae and P. aeruginosa were inhibited by beta-sitosterol and 4,4,6a,6b,8a,11,11,14b-octamethyl-1,4,4a, $5,6 a, 7,8,8 a, 9,10,11,12,12 a, 14,14 a, 14 b$,-octadecahydro- $2 \mathrm{H}$ picen-3-one, also known as beta-amyrone, which is the most abundant compound found in this fraction and first reported to be found in baobab. The activities of the ethylacetate extract reported in this study could, however, have depended on the quality and quantity of the identified chemical profile. 
Other compounds in the extract possessed various therapeutic potentials as indicated in the pharmacological section of the result. For instance, several researches have reported on the antimicrobial, antioxidant, antiproliferative and antibiofilm activities of 5-hydroxymethylfurfural (Rajkumari et al. 2019). Menthol, 1'-(butyn-3-one-1-yl)-, 1R, 2S, 5R has been reported to possess numerous pharmacological activities. Nageeb and Azeiz (2018) reported on its anticancer potential. Jamal et al. (2017) documented its antibacterial potential and Abdelgawad et al. (2018) reported its antioxidant and allelopathic activities. Adenosine, N6-phenylacetic acid, 6-octen-2-one, (Z)-, 1-di (tertbutyl) silyloxydodecane and 3-hexanol, 3-ethyl had no reported pharmacological activities from literature search. This could mean that these are new compounds not previously identified in medicinal plants. The various pharmacological activities of each compound identified in this extract, however, it is worth being considered holistically in further research activities.

\section{Conclusion}

In conclusion, this study showed that baobab fruits extract contained chemical compounds of therapeutic importance. The extract also exhibited good ferric antioxidant reducing potential, radical scavenging and antimicrobial activities, which may depend on the presence of the quality and/or quantity of these compounds in the extract. The chemical profile of compounds identified in the ethylacetate fraction justifies the use of this fruit in treating UTI in folkloric medicine as the compounds have been reported to show diverse pharmacological activities whilst further researches to isolate prominent compounds from the extract is ongoing in our lab to further isolate the bioactive compounds and test their bioactivities.

\section{Acknowledgements Competing interests}

The authors declare that they have no financial or personal relationships that may have inappropriately influenced them in writing this article.

\section{Authors' contributions}

K.O.F, D.A.A., R.M.C. and O.O.O. contributed equally to this work.

\section{Ethical considerations}

This article followed all ethical standards for research without direct contact with human or animal subjects.

\section{Funding information}

This research received no specific grant from any funding agency in the public, commercial or not-for-profit sectors.

\section{Data availability}

The authors confirm that the data created or analysed in this study are included in this manuscript.

\section{Disclaimer}

The views and opinions expressed in this article are those of the authors and do not necessarily reflect the official policy or position of any affiliated agency of the authors.

\section{Reference}

Abdallah, M. \& Ali, M., 2018, 'Antibacterial activity of leaf and stem bark extracts of Adansonia digitata against Escherichia coli and Salmonella typhi grown in Potiskum, Yobe State, Nigeria', Annals of Microbiology and Infectious Diseases 1(4), 1-7.

Abdelgawad, M.A., Labib, M.B., Ali, W.A., Kamel, G., Azouz, A.A. \& EL-Shaymaa, E.N. 2018 , 'Design, synthesis, analgesic, anti-inflammatory activity of novel pyrazolones possessing aminosulfonyl pharmacophore as inhibitors of COX-2/5-LOX enzymes: possessing aminosulfonyl pharmacophore as inhibitors of COX-2/5-LOX enzymes:
Histopathological and docking studies', Bioorganic Chemistry 78, 103-114. Histopathological and docking studies', Bioorg
https://doi.org/10.1016/j.bioorg.2018.03.011

Abiona, D.L., Adedapo, Z. \& Suleiman, M.K., 2015, 'Proximate analysis, phytochemical screening and antimicrobial activity of baobab (Adansonia digitata) leaves', IOSR Journal of Applied Chemistry 8(5), 60-65.

Adeoye-Isijola, M.O., Jonathan, S.G., Coopoosamy, R.M. \& Olajuyigbe, O.O., 2021, 'Molecular characterization, gas chromatograph mass spectrometry analysis, phytochemical screening and insecticidal activities of ethanol extract of Lentinus squarrosulus against Aedes aegypti (Linnaeus)', Molecular Biology Reports 48, 41-55. https://doi.org/10.1007/s11033-020-06119-6

Arowora, K.A., Yakubu, O.E., Shaibu, C., lornenge, T.J. \& Ugwuoke, K.C., 2019, 'Chemical composition of baobab leaves and fractionation of its ethanolic extract using column chromatography running title: Baobab leaves composition and ethanolic extract fractionation using chromatography', International Journal of Scientific Research 8(7), 812-821.

Awonyemi, I., Abegunde, M.S. \& Olabiran, T.E., 2020, 'Analysis of bioactive compounds from Raphia taedigera using gas chromatography-mass spectrometry', Eurasian Chemical Communications 2(8), 938-944.

Benzie, I.F. \& Devaki, M., 2018, 'The ferric reducing/antioxidant power (FRAP) assay for non-enzymatic antioxidant capacity: Concepts, procedures, limitations and applications', in R. Apak, E. Capanoglu \& F. Shahidi (eds.), Measurement of antioxidant activity \& capacity, pp. 77-106. John Wiley \& Sons Ltd., Hoboken, NJ. https://doi.org/10.1002/9781119135388.CH5

Bin Sayeed, M.S., Karim, S.M., Sharmin, T. \& Morshed, M.M., 2016, 'Critical analysis on characterization, systemic effect, and therapeutic potential of beta-sitosterol: A plant-derived orphan phytosterol', Medicines 3(4), 29. https://doi.org/10.3390/ medicines3040029

Braca, A., Sinisgalli, C., De Leo, M., Muscatello, B., Cioni, P.L., Milella, L. et al., 2018 'Phytochemical profile, antioxidant and antidiabetic activities of Adansonia digitata $L$. (Baobab) from Mali, as a source of health-promoting compounds', digitata L. (Baobab) from Mali, as a source of health-promoting com
Molecules 23(12), 3104. https://doi.org/10.3390/molecules23123104

Chadare, F.J., Linnemann, A.R., Hounhouigan, J.D., Nout, M.J. \& Van Boekel, M.A. 2008, 'Baobab food products: A review on their composition and nutritional value', Critical Reviews in Food Science and Nutrition 49(3), 254-274. https://doi. org/10.1080/10408390701856330

Daswani, P.G., 2019, 'Non-antibiotic potential of medicinal plants to combat urinary tract infections', Current Science 117(9), 1459-1468. https://doi.org/10.18520/ cs/v117/i9/1459-1468

Datsugwai, M.S. \& Yusuf, A.S., 2017, 'Phytochemical analysis and antimicrobial activity of baobab (Adansonia digitata) leaves and stem bark extracts on Staphylococcus aureus and Escherichia coli', Journal of BioScience and Biotechnology 6(1), 9-16.

De Caluwé, E., Halamová, K. \& Van Damme, P., 2010, 'Adansonia digitata L. - A review of traditional uses, phytochemistry and pharmacology', Afrika Focus 23(1), 11-15. https://doi.org/10.21825/af.v23i1.5037

Ebaid, H., Bashandy, S.A., Alhazza, I.M., Hassan, I. \& Al-Tamimi, J., 2019, 'Efficacy of a methanolic extract of Adansonia digitata leaf in alleviating hyperglycemia,
hyperlipidemia, and oxidative stress of diabetic rats', BioMed Research hyperlipidemia, and oxidative stress of diabetic rats', BioMed Research
International 2019, Article 2835152. https://doi.org/10.1155/2019/2835152

Elfadil, H., Fahal, A., Kloezen, W., Ahmed, E.M. \& Van de Sande, W., 2015, 'The in vitro antifungal activity of Sudanese medicinal plants against Madurella mycetomatis, antifungal activity of Sudanese medicinal plants against Madurella mycetomatis,
the eumycetoma major causative agent', PLoS Neglected Tropical Diseases 9(3), the eumycetoma major causative agent', PLoS Neglected
e0003488. https://doi.org/10.1371/journal.pntd.0003488

Emran, T.B., Rahman, M.A., Uddin, M.M., Rahman, M.M., Uddin, M.Z., Das, R. \& Layzu, C., 2015, 'Effects of organic extracts and their different fractions of five Bangladeshi plants on in vitro thrombolysis', BMC Complementary and Alternative Medicine 15(1), 1-8. https://doi.org/10.1186/s12906-015-0643-2

George, S.S., Saewan, S.A. \& Ali, R.M., 2019, 'Studying the antimicrobial activity of tamarind extract (Tamarindus indica L.), Food Science Quality Management 90 17-21. https://doi.org/10.7176/FSQM/90-04

Ghoneim, M.A., Hassan, A.I., Mahmoud, M.G. \& Asker, M.S., 2016, 'Protective effect of Adansonia digitata against isoproterenol-induced myocardial injury in rats', Anima Biotechnology 27(2), 84-95. https://doi.org/10.1080/10495398.2015.1102147

Goswami, N. \& Chatterjee, S., 2014, 'Assessment of free radical scavenging potential and oxidative DNA damage preventive activity of Trachyspermum ammi L. (carom) and Foeniculum vulgare Mill. (fennel) seed extracts', BioMed Research International 2014, Article 582767. https://doi.org/10.1155/2014/582767

Hanafy, A., Aldawsari, H.M., Badr, J.M., Ibrahim, A.K. \& Abdel-Hady, S.E., 2016, 'Evaluation of hepatoprotective activity of Adansonia digitata extract on acetaminopheninduced hepatotoxicity in rats', Evidence-Based Complementary and Alternative Medicine 2016, Article 4579149. https://doi.org/10.1155/2016/4579149 
Jamal, M.A., Rahman, M.B., Hossain, M.S., Sharma, S.P., Chung, H.J., Kim, H.J. et al., 2017, 'Antibacterial properties and chemical composition of essential oil from Aegle marmelos (L) Corr leaves growing in Bangladesh', Journal of Essential Oil Aegle marmelos (L.) Corr. leaves growing in Bangladesh', Journal of Essential Oil
Bearing Plants 20(1), 155-174. https://doi.org/10.1080/0972060X.2017.1308276

Kehlenbeck, K., Padulosi, S. \& Alercia, A., 2015, Descriptors for baobab (Adansonia digitata L.), Bioversity International, Rome, p. 57

Khorasani Esmaeili, A., Mat Taha, R., Mohajer, S. \& Banisalam, B., 2015, 'Antioxidant activity and total phenolic and flavonoid content of various solvent extracts from in vivo and in vitro grown Trifolium pratense L. (Red Clover)', BioMedical Research International 2015, Article 643285. https://doi.org/10.1155/2015/643285

Komane, B.M., Vermaak, I., Kamatou, G.P., Summers, B. \& Viljoen, A.M., 2017, 'Beauty in baobab: A pilot study of the safety and efficacy of Adansonia digitata seed oil', Revista Brasileira de Farmacognosia 27(1), 1-8. https://doi.org/10.1016/j. bjp.2016.07.001

Lisao, K., Geldenhuys, C.J. \& Chirwa, P.W., 2017, 'Traditional uses and local perspectives on baobab (Adansonia digitata) population structure by selected ethnic groups in northern Namibia', South African Journal of Botany 113, 449-456. https://doi. org/10.1016/j.sajb.2017.09.014

Muthai, K.U., Karori, M.S., Muchugi, A., Indieka, A.S., Dembele, C., Mng'omba, S. et al., 2017, 'Nutritional variation in baobab (Adansonia digitata L.) fruit pulp and seed based on Africa geographical regions', Food Science Nutrition 5(6), 1116-1129. https://doi.org/10.1002/fsn3.502

Nageeb, J.A. \& Azeiz, A.Z., 2018, 'Anticancer activity of essential oil from Lantana camara flowers against lung cancer', Journal of Chemical and Pharmaceutical Research 10(3), 108-112.

Olajuyigbe, A.A., Olajuyigbe, O.O. \& Coopoosamy, R.M., 2020, 'Interaction of Ziziphus mucronata subsp. mucronata methanol extract and first-line antibiotics is synergistic in vitro through production of reactive oxygen species',
Journal of Tropical Medicine 2020, Article 4087394. https://doi. org/10.1155/2020/4087394

Olajuyigbe, O.O. \& Afolayan, A.J., 2012, 'Pharmacological assessment of the medicinal potential of Acacia mearnsii De Wild.: Antimicrobial and toxicity activities', International Journal of Molecular Sciences 13(4), 4255-4267. https://doi. org/10.3390/ijms13044255
Olajuyigbe, O.O., Onibudo, T.E., Coopoosamy, R.M., Ashafa, A.O.T. \& Afolayan, A.J., 2018, 'Bioactive compounds and in vitro pharmacological effects of ethanol stem bark extracts of Trilepisium madagascriense DC', International Journal of Pharmacology 14(7), 901-912. https://doi.org/10.3923/ijp.2018.901.912

Rajkumari, J., Borkotoky, S., Reddy, D., Mohanty, S.K., Kumavath, R., Murali, A. et al., 2019, 'Anti-quorum sensing and anti-biofilm activity of 5-hydroxymethylfurfural against Pseudomonas aeruginosa $\mathrm{PAO} 1$ : Insights from in vitro, in vivo and in silico studies', Microbiological Research 226, 19-26. https://doi.org/10.1016/j. micres.2019.05.001

Rathee, P., Chaudhary, H., Rathee, S., Rathee, D., Kumar, V. \& Kohli, K., 2009, 'Mechanism of action of flavonoids as anti-inflammatory agents: A review', Inflammatory Allergy Drug Targets 8(3), 229-235. https://doi. org/10.2174/187152809788681029

Saeidnia, S., Manayi, A., Gohari, A.R. \& Abdollahi, M., 2014, 'The story of betasitosterol - A review', European Journal of Medicinal Plants 7, 590-609. https:// doi.org/10.9734/EJMP/2014/7764

Santos-Sánchez, N.F., Salas-Coronado, R., Villanueva-Cañongo, C. \& HernándezCarlos, B., 2019, 'Antioxidant compounds and their antioxidant mechanism: En Emad Shalaby', in Antioxidants, pp. 1-28, Intech Open, London. https://doi. org/10.5772/intechopen.85270.

Sharma, R., Zimik, M. \& Arumugam, N., 2018, 'Isolation and GCMS characterization of certain non-polar compounds from Spilanthes ciliata', International Journal of Pharmacy and Biological Sciences 8(4), 889-903.

Sodimu, A.I., Usman, M.B., Appah, J., Osunsina, O., Suleiman, R.A., Maikano, S. et al., 2020, 'Ethnobotanical survey of medicinal utilization and phytochemical composition of baobab tree (Adansonia digitata L.) in Zaria local government area of Kaduna state, Nigeria', European Journal of Medicinal Plants 31(5), 1-10. https://doi.org/10.9734/ejmp/2020/v31i530233

Sundarambal, M., Muthusamy, P. \& Radha, R., 2015, 'A review on Adansonia digitata Linn', Journal of Pharmacognosy and Phytochemistry 4(4), 12-16.

Tembo, D.T., Holmes, M.J. \& Marshall, L.J., 2017, 'Effect of thermal treatment and storage on bioactive compounds, organic acids and antioxidant activity of baobab fruit (Adansonia digitata) pulp from Malawi', Journal of Food Composition and Analysis 58, 40-51. https://doi.org/10.1016/j.jfca.2017.01.002 